\title{
Article
}

\section{It Doesn't Add Up: myths and measurement problems of births to single women in Blackpool, 1931-1971}

\author{
Hobbs, Andrew
}

Available at http://clok.uclan.ac.uk/25640/

Hobbs, Andrew ORCID: 0000-0001-5943-475X (2008) It Doesn't Add Up: myths and measurement problems of births to single women in Blackpool, 1931-1971. Women's History Review, 17 (3). pp. 435-454. ISSN 0961-2025

It is advisable to refer to the publisher's version if you intend to cite from the work. http://dx.doi.org/10.1080/09612020801924571

For more information about UCLan's research in this area go to http://www.uclan.ac.uk/researchgroups/ and search for < name of research Group>.

For information about Research generally at UCLan please go to http://www.uclan.ac.uk/research/

All outputs in CLoK are protected by Intellectual Property Rights law, including Copyright law. Copyright, IPR and Moral Rights for the works on this site are retained by the individual authors and/or other copyright owners. Terms and conditions for use of this material are defined in the policies page.

\section{CLoK}

Central Lancashire online Knowledge www.clok.uclan.ac.uk

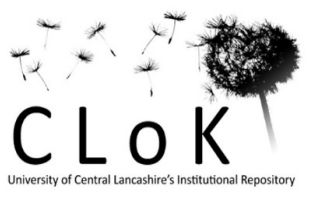




\section{It Doesn't Add Up: myths and measurement problems of births to single women in Blackpool, 1931-1971}

Andrew Hobbs

This is an Author's Accepted Manuscript of an article published in Women's History Review Vol. 17, No. 3, July 2008, pp. 435-454, copyright Taylor \& Francis, available online at:

http://www.tandfonline.com/doi/abs/10.1080/09612020801924571

\section{Abstract}

This article examines the usefulness of demographic methods for the study of births outside marriage, using Blackpool as a case study. It attempts to show that statistics collected for medical purposes were misinterpreted, producing a historical myth about the sexual behaviour of single women in seaside resorts. More sophisticated demographic methods reveal that the fertility of single women in Blackpool was unremarkable, but these methods are unable to describe highly seasonal local economies such as Blackpool. This case study suggests that the dichotomies of single/married and legitimate/illegitimate are incoherent, and that birth statistics can reveal little about sexual behaviour.

\section{Introduction}

Blackpool, the world's first working-class seaside resort, had a reputation for saucy seaside fun throughout the twentieth century. ${ }^{1}$ Another reputation, not unrelated, was for its remarkable numbers of single women giving birth to 'illegitimate' children. This second claim to fame was established through statistics published by local Medical Officers of 
Health, amplified by the press, noted by commentators such as Mass Observation, and used by historians to draw conclusions about the sexual behaviour of single women and the impact of the tourism industry on family structure. ${ }^{2}$

This article will show that the story of high birth rates to single women in Blackpool is a myth based on misleading statistics that problematised births to single women while hiding the unusual fertility behaviour of other women. More sophisticated demographic methods reveal that the fertility of single women in Blackpool was unre markable, but even these statistical techniques cannot accurately measure birth rates in local economies subject to seasonal migration. The conceptual foundations of these demographic methods, involving the dichotomies of single/married and legitimate/ illegitimate, are shown to be inadequate in describing the complex lives of historical people, and birth statistics are therefore seen to be a poor indicator of sexual behav iour. Blackpool is unlikely to have been unique in its demography and seasonal econ omy, so the problems of demographic approaches for this locality raise issues of general importance.

Blackpool, on the Lancashire coast, fifty miles north-west of Manchester, was transformed from a scattered coastal agricultural settlement into a lively seaside town in the late nineteenth century. ${ }^{3}$ It was similar to other English seaside resorts in its seasonality, its population structure (higher proportions of unmarried younger women and married older women, lower proportions of men-see Table 1), its rapid population turnover and its association with illicit sex and births outside marriage. However, Blackpool had its differences-its season was longer than most (thanks to the Illuminations in September and October, first switched on in 1912), it had more poverty, ${ }^{4}$ the economic and social gap between the providers of tourism services and their consumers was smaller, and it experienced the fastest growth of any British resort in the early decades of the twentieth century, doubling its population between 1901 and 1921. By the mid 1930s it was Britain's most popular resort, with some seven million visitors each year.

The literature on English seaside resorts is limited. A great deal of research is still required to support any generalisations about such a widely spread and various collec tion of towns and villages. However, some historians and geographers have applied the tools of socio-economic 
history to the huge industry that serviced the tourist experi ence, 5 focusing on the Victorian, Edwardian and inter-war periods. However, post-war histories of the British seaside are sparse, covered only by Walton in any depth. ${ }^{6}$ Each historian has tended to focus on a small number of resorts in detail, with Walton lead ing the field in his studies of Blackpool.

Blackpool's astonishing growth from the 1880s to the 1950s was achieved mainly through migration. ${ }^{7}$ Even after population growth stopped in the 1950s, migration and a high turnover of population continued. The Second World War brought economic benefits to Blackpool, thanks to armed forces personnel there for training or convalescence, civil servants transferred from London, evacuees, and large-scale aircraft production. Seaside holidays, good for morale, continued unabated. ${ }^{8}$ After the war the town's demography changed, with a static census population but more elderly residents and more commuters, linked to a decline in the relative importance of the holiday industry to the local economy. ${ }^{9}$

Table 1. Male:female sex ratio, Blackpool, England and Wales. Source: Census (1931, 1951, 1961, 1971), National Registration (1939).

\begin{tabular}{lcc}
\hline & England and Wales & Blackpool \\
\hline 1931 & $48: 52$ & $43: 57$ \\
1939 & $47: 53$ & $43: 57$ \\
1951 & $48: 52$ & $44: 56$ \\
1961 & $48: 52$ & $45: 55$ \\
1971 & $48: 52$ & $45: 55$ \\
\hline
\end{tabular}

Seaside resorts were predominantly female places, both in terms of tourists and the workers who served them. ${ }^{10}$ While such work was sometimes sexualised, with wait resses and other female workers encouraged to dress in stereotypically feminine clothes and to accept sexual innuendoes from male customers, ${ }^{11}$ there were also opportunities for women to gain economic and social power, for example, by running a boarding house (a respectable way of preserving the standard of living of widows, deserted wives and spinsters). ${ }^{12}$ 
A demographic study such as this is necessarily bounded by census years, in this case beginning in 1931 , to allow some calibration of the impact of wartime. It was also the census year before the first claim that Blackpool's births outside marriage were note worthy (made by MassObservation in 1938), ${ }^{13}$ and the first census since the return of Blackpool's Illuminations, the attraction that gave the resort its unusually long season. The period can be divided into four: the 1930s, with its unprecedentedly low birth rate; the upheaval of the Second World War; the post-war marriage boom; and the changing sexual and marital mores of the 1960s, when the wider availability of contraception and the 1967 Abortion Act weakened the connections between sexual activity and childbirth.

Little demographic work has been done on twentieth-century births outside marriage and this article will suggest that any attempt to do so faces major conceptual problems. Such births became a subject for study and debate in the early nineteenth century, influenced by Malthus and his view that the old Poor Law encouraged the phenomenon. ${ }^{14}$ Malthus's theories influenced the 1834 Poor Law Amendment Act, which reduced the powers of local authorities to ensure support from the fathers of natural children, making the mother solely responsible for the child's upkeep in a majority of cases. ${ }^{15}$ Growing interest in population statistics, gathered from the first censuses of the early nineteenth century, and newly introduced civil registration of births in 1837, prompted social investigators, doctors and others to examine the 'prob lem' of births outside marriage. Interest in the issue declined in the late nineteenth and early twentieth centuries, when it was seen simply as a moral matter, but in the 1930s, anxiety over the decline of the 'national intelligence' and the association of unmarried motherhood with mental subnormality inspired new interest in the fields of history, social investigation and campaigning. Most general and social histories of extramarital births, such as those by Hartley, Hopkirk and Gill, rarely went beyond description to challenge contemporary attitudes (exceptions are the more analytical Wimperis and Kiernan, Land and Lewis). ${ }^{16}$ From the 1960 s to the 1980 s, the new discipline of histor ical demography, aided by developments in sociology and computing, appeared to offer new opportunities. Ansley Coale in the USA and Peter Laslett in Britain led major research projects, crunching millions of numbers from many centuries to offer a long view of changing fertility behaviour, attempting to place births outside marriage in the wider context of all births and all marriages. ${ }^{17}$ 
More recently, Andrew Blaikie and his team have been able to combine the two strands of historical demography - family reconstitution and population statistics - in their study of nineteenth-century Scot tish demography, using record linkage and biography for a more multidimensional approach to fertility and family formation. ${ }^{18}$

However, demographic approaches are condemned by Gail Reekie in a devastating critique of 'social enquiry's persistent obsession with illegitimacy'. Building on Teichman's philosophical analysis of the concept, Reekie uses Foucauldian techniques to excavate the meanings of the category, exposing it as an incoherent, gendered tool of control. ${ }^{19}$ For these and other reasons, historiographical attention has turned away from measurement of the phenomenon, towards personal experiences of mothers, fathers and children 20 and to cultural histories such as those of Fink and Holden, ${ }^{21}$ focusing on the wider meanings of singleness for women, further challenging the categories of marriage and 'illegitimacy'.

Not all extra-marital births are the same: they can issue from sex between people who are single, widowed or divorced, between a married person and an unmarried person, or from cohabitation. Incestuous relationships must also be considered. Births to never-married women, regardless of the father's status, have been seen as the most problematic, although they probably accounted for less than a third of all 'illegitimate' births. ${ }^{22}$ Why this focus on single women, rather than on the greater numbers of married, cohabiting, divorced, separated and widowed mothers, or the other half of the picture, the fathers?

Unmarried mothers were more likely to be a public cost: they were visibly without the support and control of a man, ${ }^{23}$ their deviance cast the institution of marriage in a good light, 24 and it was harder to hide their situation than that of other mothers of 'illegitimate' children, such as married or cohabiting women. Of particular signifi cance to this article is the way in which they were believed to stand for something more than themselves, 25 'an index of social disorganisation, immorality, and of the family's loss of cohesiveness and control', 26 sometimes even as a sign of national and racial degeneration. 27 


\section{Representations of Single Mothers, 1931-1971}

The ways in which single mothers were represented during this period were part of the framework within which local and national statistics were interpreted and understood. Fink and Holden identify three main representations, competing and co-existing with each other: the selfsacrificing mother/innocent victim; the fallen woman, and the mentally impaired. In Blackpool, local circumstances and culture produced two vari ants: the outsider sullying the town's name, and the bad girl.

The single woman as innocent victim and self-sacrificing mother, apparent in mid nineteenth-century novels such as Elizabeth Gaskell's Ruth (published 1853), reap peared in popular films of the 1930 s and 1940 s. $^{28}$ The self-sacrificing mother was also part of the discourse of the homes for unmarried mothers and their babies, usually run by church organisations, which operated from the 1920s to the 1960s. The Catholic organisation covering Blackpool was the Lancaster Roman Catholic Diocesan Rescue and Protection Society, founded in 1934 'to help Catholic children to save their souls' ${ }^{29}$ Single mothers were only a small part of its work and Blackpool a small part of its patch, so the annual reports (intended for public consumption and for fund-raising) must be interpreted cautiously. However, these annual reports are surprisingly non-judgmental, an approach consistent with Fink's analysis of similar Anglican organisations, with their shared view that unmarried motherhood was the result of personal lapse. ${ }^{30}$ Another reason for a more sympathetic view of unmarried motherhood may have been fears of a population decline in the UK in the 1930s (the birth rate had more than halved, from 23 births per 100 married women in 1901-05 to 11 per 100 in 1931-35), so that any babies, even 'illegitimate' ones, were welcome. 31

The compassionate, pitying discourse is typified by a comment in the 1936 report and accounts of the Lancaster Catholic Rescue Society: 'Who would deny assistance to a young girl who has got into trouble, maybe through innocence, and we must emphatically state that a girl does not receive help a second time'. 32 Note the awareness of the weak link between sexual licence and extra-marital births, combined with the firm caveat that 'repeaters' would not be entertained. A year later, in 1937, Blackpool council tried unsuccessfully to create a new by-law to control servants' registries (employ ment agencies), to meet concerns that young 
girls who failed to find service jobs would 'resort to an immoral mode of life' ${ }^{33}$ Similar concerns were expressed during the war, over the perceived threat from large numbers of servicemen billeted in Blackpool. 34

Church organisations could accept that a 'one-off' single mother could be the result of a lapse, but women expecting a second 'illegitimate' child were usually sent to the workhouse hospital or its successors. ${ }^{35} \mathrm{~A}$ second child out of wedlock was the mark of the fallen woman, the second representation to be considered here. Fink and Holden trace this more negative image back to the nineteenth century and even earlier, and link its reappearance in the 1950 s and 1960 s to a renewed focus on marriage and a more masculine popular culture. 36

A third representation sees unmarried mothers as psychologically deviant. In the 1930s many were placed in the category of the 'feebleminded' (the borderland between 'normal' intellect and 'idiocy', thought to connect criminality, poverty and promiscuity). ${ }^{37}$ The 1913 Mental Deficiency Act was used particularly harshly against the 'illegitimate' daughters of 'illegitimate' women, 38 due to eugenic beliefs that they were 'contributing to the problem of racial degeneracy and thereby to Britain's decline as an international and imperial power' ${ }^{39}$ A different psychological basis for unmar ried motherhood-neurosis-was put forward in the 1950s, by Leontine Young in the United States and John Bowlby in the UK. 40

In Blackpool, there were two local variants in the representation of the never married mother: the outsider and the bad girl. The outsider sullying Blackpool's name is found in the annual reports of Blackpool's Medical Officers of Health ( $\mathrm{MOHs}$ ) and in local press coverage of these reports and of comments from other public figures. The post of $\mathrm{MOH}$ (filled by three incumbents in Blackpool during the period) has an honourable tradition stretching back to the nineteenth century. Its responsibilities grew with the welfare state, encompassing the school medical service; health programmes for mothers and children (partly inspired by imperialist and eugenicist concerns) such as antenatal and infant welfare clinics, health visitors and midwives; infectious disease control (including sexually transmitted diseases), pest control, food safety and from 1929 in some areas (but not Blackpool), control of former Poor Law hospitals. $\mathrm{MOH}$ also had an advisory role in slum clearance and housing. After the creation of the National Health Service in 1948 they lost control of municipal 
hospitals and some clin ics, and in 1971 some duties were moved to the newly created social service depart ments. In 1974, when the National Health Service was reorganised, the post of $\mathrm{MOH}$ was abolished. 41 Reporting and commenting on 'illegitimate' births was thus a small part of their duties and in annual reports of forty to eighty pages would merit between six lines and two pages, including reference to facilities for mothers and babies.

MOHs were high-profile figureheads, and appear to have had wide scope in interpreting their duties in line with their personal interests and local situation, including the politics of the councillors who employed them. Some went against, or lagged behind, national orthodoxy, while others pioneered significant advances in public health. ${ }^{42}$ In Blackpool, the first $\mathrm{MOH}$ during this period, Dr E. W. Rees Jones, served from 1908 to 1940, when he was replaced by his assistant, Dr George W. Murray. Murray served from 1940 to 1958, and was in turn replaced by his deputy, Dr David W. Wauchob, in 1959, until the abolition of the post in 1974 . This line of succession through promotion would have encouraged the continuation of a consistent profes sional ethos, which is apparent in the annual reports of the first two MOHs, until the third, Wauchob, introduced a more liberal and outspoken tone.

I have been unable to discover the rationale behind the Ministry of Health require ment for $\mathrm{MOHs}$ to report the proportion of births to single mothers in their district (the 'illegitimacy ratio'), but there could be sound public health reasons: rates of death and illness were generally far higher among children born outside marriage (although this was rarely mentioned in the Blackpool $\mathrm{MOH}$ reports). ${ }^{43}$ The birth statistics were obtained not from local sources but from the Registrar-General's office.

The 1930s were a time of national concern at the low birth rate, when unmarried motherhood was associated with 'feeble-mindedness' and prostitution. Apart from a time series of 'illegitimacy ratios' for 1907-30 in the 1930 report, the Blackpool $\mathrm{MOH}$, Rees Jones, commented on the number of 'illegitimate' births only once in this decade, in 1936, when he described a fall in the proportion of such births as a 'gratifying improve ment'. However, he regularly recorded the high proportion of such births at Kirkham Workhouse, later known as the Fylde Institution (in some years all births at this hospital were illegitimate, ranging from eleven in 1932 to three in 1937). No comment is ever made on these figures, but identifying these births may have reinforced contemporary beliefs that the mothers (who 
had probably already borne at least one child outside marriage) were mentally subnormal and a threat to the nation's health. ${ }^{44}$ Rees Jones's successor, Murray, does not single out births at the Fylde Institution hospital.

For Rees Jones, the low birth rate appeared to be a more pressing concern than births outside marriage. For example, in 1930, he attributes Blackpool's figures to the fact that 'our proportion of married women of child-bearing age is small as compared with that of industrial towns'. 45 And in 1934 and subsequent years, he makes clear that contraceptive advice is 'limited to cases where further pregnancy would be detrimental to health ... the cases are selected with the most meticulous care', implying that many requests were refused in this pro-natalist era. 46

Nationally, these concerns faded during wartime and in the postwar baby boom, but in Blackpool they remained. The next $\mathrm{MOH}$, Murray, noted in 1945: 'There is an increasing tendency to make use of the facilities offered [at the birth control clinic], and a close watch must be maintained as advice is not given on purely economic grounds'. The clinic was for married women only. In 1951 and 1953, Murray writes of the same service: 'It should be stressed that this is not a family planning clinic'.

While his predecessor commented on births outside marriage only once in the ten annual reports sampled, Murray expressed an opinion on the subject seven times in his eighteen reports, both in wartime and after. During the war he was able to explain away the high ratio of births outside marriage as 'an unfortunate but expected result of war conditions', 47 or, in 1945 , because a hostel for ex-service pregnant women had opened in the town. In the late 1940s and early 1950s, attempts at explanation were replaced by expressions of concern when the numbers went up, or rare pleasure when they came down.

In 1947, council-sponsored services to unmarried mothers and children are mentioned for the first time, and from then on become a regular item in the reports. Blackpool did not employ a social worker, 'as it is considered that the District Health Visitors in collaboration with the [Anglican] Fylde House of Help and the [Catholic] Lancaster Diocesan Rescue Society can adequately cover all aspects of welfare work for the unmarried mother and her child'. ${ }^{48}$ Grants were made to these two voluntary organisations, and from 1949 onwards, figures were given for councilfunded placements in mother and baby homes (ranging from four to 
eleven per year). In 1968, while such homes were closing around the country, 49 a new one, Ashcroft House, was opened by the Methodist Church in Blackpool, with five of its eight beds funded by the council. 50

While the first two medical officers of the period seemed opposed to the very principle of contraception, the third, Wauchob, oversaw support for the local Family Planning Association. In 1959, the year he took charge, the FPA were for the first time allowed to hold clinics on council premises, and took on the council's entire caseload. Other signs of liberalism can be found in his comments on requests for abortions in 1968, when he hoped that more resources for this new service would reduce maternal and child deaths and 'illegitimacy'.

Wauchob is the only $\mathrm{MOH}$ to appear in the cuttings file of the local paper, the West Lancashire Evening Gazette, under the classification 'Children-illegitimate births'. After 1948, it was not uncommon for MOHs to use the media in this way. ${ }^{51}$ In his annual reports, too, he became increasingly outspoken, commenting on the subject ten times in his fifteen reports. In 1962 he appeared to reject the ideas of Young and Bowlby that unmarried mothers were neurotic. Referring to Blackpool's high ratio of births outside marriage, he wrote: 'These figures reflect a way of life rather than illness' ${ }^{52}$ In later years, as sexual mores appeared to change rapidly, Wauchob became less tolerant, blaming 'permissiveness' for higher rates of sexually transmitted diseases in the 1970 and 1972 reports, and for 'illegitimate' births in the latter. In the same report he disparages mothers who consciously choose to remain single, influenced by 'some single mothers who are in vastly better financial circumstances than those who attempt to follow their trendy patterns of living'. 53

But when discussing individual women, or the services available to them, the tone of voice was consistently matter-of-fact, or compassionate and pitying. As Reekie says: 'As a culture we are reluctant to morally condemn or penalise individual women and chil dren, yet we easily judge as bad the abstract social phenomenon of single parent hood' ${ }^{54}$ This supports Fink's view of the ambivalent, confused discourse surrounding unmarried mothers, veering between condemning and condoning, revealing a disso nance between accepted public discourse and personal experience. 55

There is less variation in the annual reports of the Lancaster Diocesan Rescue Society and in local newspaper coverage of annual reports and 
meetings of the Fylde House of Help, than in the MOH's annual reports. These sources generally have a non-judgmental tone with occasional attacks on 'lowering of moral standards' (1941) 56 and 'promiscuity' (1965). 57 There are hints at wider changes, such as wartime concerns over the 'national necessity' of 'increased population' 58 and young people's fatalism, 59 and in the 1950 s, 'coloured' babies 60 and fears over declining family support for unmarried mothers. 61

The predominant view of extra-marital births in Blackpool throughout this period was that most of them were to outsiders. 'It is not your own people. It is people who come in from those other places, those who run away to this marvellous place', Canon F. Paton-Williams, Rector of St Ann's Church, Manchester told a Blackpool public meeting in 1939. 62 'Many girls expecting illegitimate children came to Blackpool to have them, away from their own home towns ... Many babies are born here while their mothers are on holiday ... Some seasonal workers who became pregnant did not return home to have their babies', according to an unnamed 'local medical authority' (not the $\mathrm{MOH}$ ) in 1959, quoted in a newspaper article headlined 'Birth Figures No Reflection on Blackpool-says doctor'. 63 Similar comments were found from the 1930s through to the 1970s in local press articles, and particularly in the reports of the third $\mathrm{MOH}$, Wauchob. In 1960 he commissioned a survey to determine how many unmarried mothers were local. Health visitors questioned ninety-eight women, finding that fifty had been resident in Blackpool at the time of conception, and forty had been resident elsewhere, with the location unknown for the remaining eight. ${ }^{64}$ The $\mathrm{MOH}$ continued to use these figures into the $1970 \mathrm{~s}$ to support his belief that Blackpool's high figures were due to outsiders, yet, as we shall see, it is doubtful whether such births were included in the town's statistics. 65

The second local image of the never-married mother, prevalent in the 1930s and during the war, was of the 'bad girl', a precocious sexual predator, the kind of girl envis aged by the 1933 Children and Young Persons Act, which empowered local authorities to bring any girl before a juvenile court and have her sent to an approved home if she was considered a danger to herself and to young men in the neighbourhood; such girls also came within the remit of moral welfare associations. 66 In 1941, Blackpool was swollen by large numbers of evacuees and servicemen (the town was the 
biggest receiv ing centre for evacuees in the UK, and three-quarters of a million RAF recruits passed through it during the war) ${ }^{67}$ when Alderman Grime, proprietor of the Evening Gazette, used his columns to claim that 1316-year-old girls were 'out of hand' and 'morally and physically contaminated', were having sex with soldiers and that there was an increase of venereal disease (VD) among them. School inspector P. F. Burns reported this to the Board of Education in London, quoting a gynaecologist's claim of over 300 unmarried expectant mothers in Blackpool, and high rates of VD among 15-year-old girls reported to the Young Women's Christian Association (YWCA). On investigation, all the claims were found to be false. ${ }^{68}$ This confirms Mass-Observation's 1937 report on Blackpool, which found the stereotype of the bold, flirtatious Lancashire lass alive and well; but while she wasn't being good, she was being careful. ${ }^{69}$ Working-class Lancashire women had a reputation for independence that stretched back to the mid nineteenth century, founded on the opportunities for paid female employment in the textile industry, as represented in Elizabeth Gaskell's North and South (1855), Stanley Houghton's controversial drama Hindle Wakes (1912) and the Gracie Fields film Sing as We Go (1934). 70

Mass-Observation may have been middle-class outsiders, but their research in Bolton had taught them to spot a 'knee-trembler' in the dark 71 and they were disappointed to find so little sex in Blackpool. It was all talk, they concluded. The Lancashire mill girl is:

seldom prepared to let a man have his way unless she knows him, his background, his earnings, his health, where he can be found again, and whether he will be ready to take her out and love her some more. To most mill girls, sex is still definitely linked to the idea of marriage. ${ }^{72}$

\section{Measurement Problems}

The common-sense assumption behind the 'bad girl' image of the young single mother, that births outside marriage are directly linked to sexual behaviour, was the impetus for this research (the intention was to examine the impact of the tourist industry on sexual mores and family structure). This took for granted 'the notion that there is a self-evident, measurable 
distinction between marital and non-marital births' ${ }^{73}$ However, this section will suggest that on technical grounds alone, the difficulties in measuring non-marital births appear almost insurmountable, and that the category of 'illegitimate births' is far from self-evident. 74

Blackpool's reputation for extraordinary rates of extra-marital births is founded on the statistics published by the Medical Officer of Health (based on those published by the Registrar-General) at the behest of the Ministry of Health. These statistics were known as 'illegitimacy ratios', the number of births outside marriage as a proportion of all births. Blackpool regularly ranked in the top ten per cent of local authorities in England and Wales, sometimes at twice the national level, and well above the rest of Lancashire (see Figure 1). These figures were reported by the local press, used by Mass-Observation, and quoted by historians. ${ }^{75}$ At a national level, commentators and social scientists such as Hopkirk and Gill used this ratio unquestioningly, to compare areas of England, Wales and Scotland. 76

But the illegitimacy ratio, or extra-marital birth ratio, is meaningless by itself, for two reasons: it depends on the number of births inside marriage, and it takes no account of the number of unmarried women of fertile age available to produce births outside marriage. The ratio is a simple fraction: births outside marriage divided by total births i.e. births outside marriage + births inside marriage. The bottom line of this fraction is made up of births to married women, plus births to unmarried women. So variations in the married birth rate will affect this ratio, regardless of any changes in the unmar ried birth rate. And births to unmarried women are likely to vary according to the numbers of such women in the local population. Like many other tourist economies, Blackpool's high proportion of unmarried to married births is partly due to greater numbers of young, unmarried women drawn to the area for employment, but is mainly caused by fewer births to married women (see Table 2), who tended to be older and therefore less fertile. ${ }^{77}$ So if Blackpool is unusual in anything, it is in the low fertility of its married women. 


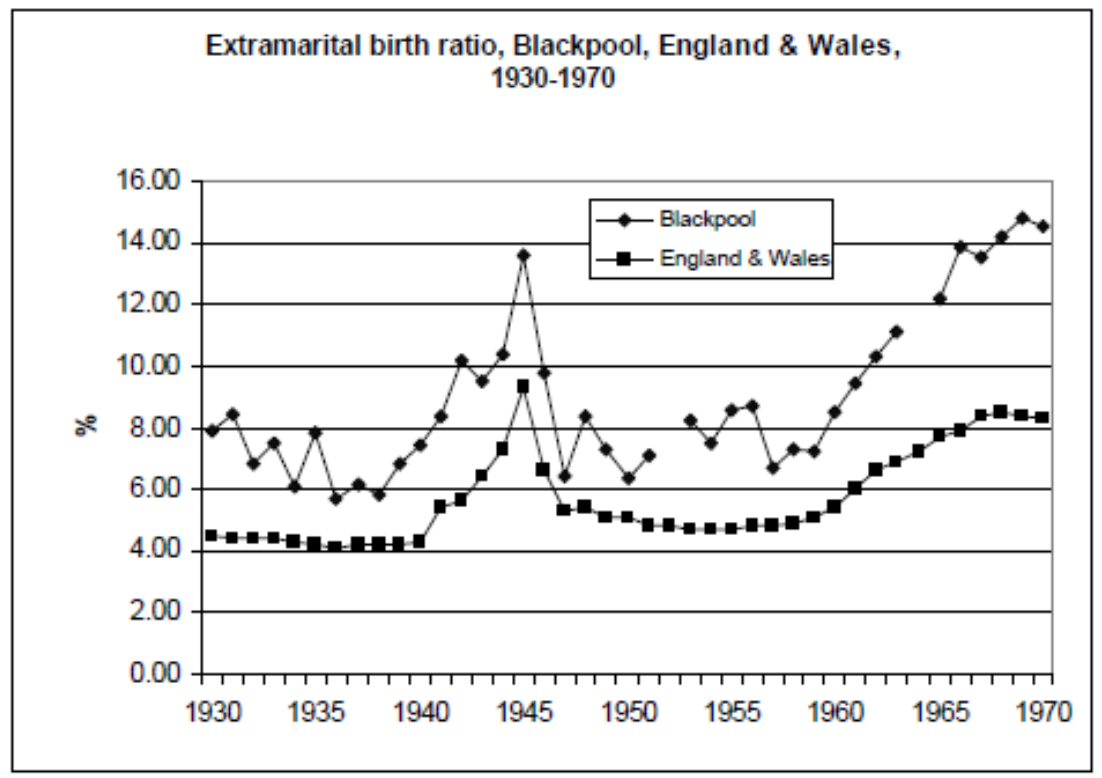

Figure 1. Extra-marital birth ratio ('illegitimate' births as a proportion of all births), Blackpool, England \& Wales, 1930-1970. Source: Blackpool Medical Officer of Health reports, Registrar General annual reports.

More sophisticated ways of describing births outside marriage relate them to the number of single, divorced and widowed women in the population (the General Extra-marital Fertility Rate), and to the ages of these women, to account for variations between populations in numbers of women at the age of peak fertility (Coale's $/ h$ index). When these methods are used, Blackpool's rate of extra-marital births appears to have been higher than the national average, but usually lower than other large Lancashire towns (Figure 2). I have been unable to find any studies of industrial Lancashire's higher rates of births outside marriage in the twentieth century.

Table 2. Births per 1000 married women aged 15-44, 1931. Source: Registrar General's annual statistical review for 1931.

\begin{tabular}{ll}
\hline Blackpool & 80.6 \\
Lancashire & 132.9 \\
England and Wales & 122.8
\end{tabular}




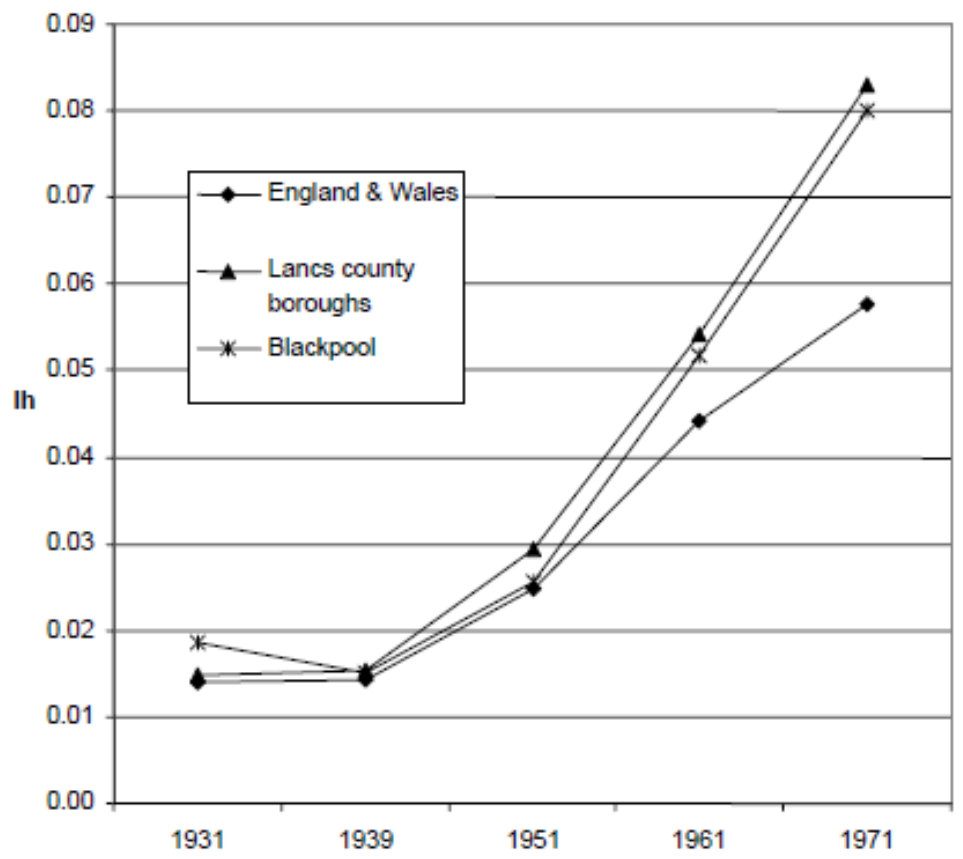

Figure 2. Coale's Index of age-related extra-marital fertility (Ih), selected areas, 1931-71. Source: Census (1931, 1951, 1961, 1971), National Registration (1939) and Registrar General's annual statistical reviews.

The myth of Blackpool's high rates of extra-marital births is further weakened when seasonal migration is taken into account. Migration is notoriously difficult to track with census data taken on one day per decade, ${ }^{78}$ yet the most sophisticated measures of births outside marriage depend on such data. The General Extra-marital Fertility Rate, and Coale's Index $(/ h)$ both rely on the calculation of extra-marital births allocated to Blackpool (source: Registrar General) divided by the number of single women in Blackpool (source: Census), in which births from Registrar General records for a twelve-month period are cross-referenced to numbers of unmarried, divorced or widowed women present on census night of the same year (which means that this calculation can only be made for census years).

Measures based on census population figures will exclude seasonal migrants, while potentially including extra-marital births to these migrants, thus inflating standard demographic measures. It seems likely that Blackpool's figures will be artificially inflated, because in many 
cases, the babies will be recorded, but the mothers will not. These women may not yet have arrived in Blackpool at census time (April), they may have given their 'usual residence' as an address outside Blackpool, or there could have been a score of other reasons. The census is usually taken in April, before the main holi day season has begun, so an April census will exclude the thousands of seasonal migrant workers who come to Blackpool at the start of the summer season and stay there until September or late October when the Illuminations are switched off. If any of these seasonal migrants gave birth to a natural child in Blackpool, it could potentially appear in the top part of the equation while its mother-and all her seasonal migrant sisters - are absent from the bottom part.

There is further scope for confusion when we consider how unmarried seasonal migrants might choose to define 'usual place of residence', when they registered their child's birth. Births away from home were 'assigned' by the Registrar General to the parents' usual place of residence (a process not always understood by Medical Officers of Health), to assist in accurate local planning. But there could be many reasons for single mothers giving their temporary Blackpool address rather than a home address. Perhaps their family lived in Blackpool and-although settled elsewhere-they returned home to give birth, or they came to Blackpool specifically to give birth to a 'natural' baby and were afraid of people back home finding out, if they gave their home address. They may have come to Blackpool after being thrown out by their family, and no longer felt able to call their family address 'home'. Or they may have misunderstood the question and simply gave their current, temporary Blackpool address. Similar measurement problems apply to many other areas where seasonal trades such as tourism, fishing, agriculture, even higher education are a significant part of the local economy.

\section{Illegitimate Inferences}

Some weaknesses of these demographic methods could be overcome through record linkage, as in the work of Blaikie and Jones on nineteenth-century births outside marriage in Scotland and Essex respectively, but lack of access to census enumerators' books and birth registrations for mid-twentieth-century England precludes this. ${ }^{79}$ 
Biographical and autobiographical material, case notes and oral histories (not without their own difficulties as historical sources) are also needed to ascertain individuals' understandings of official concepts such as 'usual place of residence' or single/ married. 80

Demographic methods based on the dichotomy of single/married are inadequate for capturing the complexity of parental arrangements and domestic circumstances. They tell us nothing about children born to married women and fathered by men who are not their husbands, or about children born to cohabiting couples. These are significant omissionsbetween a half and a third of mothers of extra-marital babies described themselves as 'married', according to two studies that cross-referenced birth registrations with returns from the 1961 and 1971 censuses, 81 while Hartley found two-thirds of the mothers (married or unmarried) were cohabiting with a man other than their husband. 82 Pearce and Farid suggest two explanations for this anomaly: either these women considered themselves married in a 'common law marriage' (cohabitation), or they were married to someone other than the father of the child. There must also be an unknown number of other children of married women, whose fathers are not their mother's husbands, but whose birth certificates hide this fact. Demographers them selves recognise the problems of measuring births outside marriage in the second half of the twentieth century (while defending their use for earlier periods); Ansley Coale, who developed the most sophisticated ways of measuring fertility, admitted that 'the changes in nuptiality occurring in Europe make the analysis of fertility in terms of marital status and marital fertility obsolete' ${ }^{83}$

However, there is good evidence that cohabitation and 'illegitimate' births to married women are not new phenomena, raising doubts over demographic studies based on the category of marriage in any era. During the First World War enough 'common-law marriages' came to light for the British Government to eventually pay the same Separation Allowances to unmarried women with partners in the Forces as to legally married wives, 84 and Kiernan and Estaugh suggest that 'cohabitation after a marriage breaks down and between marriages is unlikely to be a recent development. Common sense alone would suggest that in periods when divorces were less easy to obtain, people might choose to cohabit' 85

Joanne Klein's study of police personnel records in Liverpool, 
Manchester and Birmingham found that 'more flexible ideas of matrimony', including cohabitation, affairs and other unorthodox domestic arrangements, were still common to respectable working-class culture up until the Second World War. 86 Thus, case linkage allows us to estimate the proportion of extra-marital births to women who consider themselves married, but the category we have been using to define a particular set of births - marriage-appears less and less useful. If marriage, or a partnership suitable for bring ing up children, is self-defined by many parents in defiance of official definitions (as appears from the evidence of pre-marital conceptions and cohabitation throughout the twentieth century), then the categorisation of certain births by the parents' marital status becomes highly problematic.

Extra-marital births have been seized on by social researchers and historians because they seem to offer an objective, public, proxy indicator of a very private activity, sexual behaviour. Mass-Observation used them, 87 and Humphries includes Blackpool in his collection of oral histories of illicit sex:

one of the few ways we can begin to gauge how much sex was going on at the seaside, with hard statistics, is by looking at birth rates ... During the inter-war years ... Blackpool found itself with one of the highest illegitimacy rates in England. In some years, for example 1922 and 1928, it spiralled to ten per cent, and in many others it was around the 8 per cent mark-about twice the national average. 88

Szreter describes extra-marital birth rates as 'a gross measure of plebeian sexual "respectability" 89 and Cook confidently states that twentieth-century trends in illegitimacy reflect changing levels of sexual activity outside marriage. 90 But the link between sexual behaviour and the registration of a birth as 'illegitimate' is a weak one. ${ }^{91}$ Laslett put this well when he described figures for such births as measures of 'the extent to which people were willing to allow a whole series of things to happen, mostly to themselves, rather than measures of the frequency with which acts risking a regular impregnation in fact occurred'. 92

Figure 3 (drawn especially for this article) presents what that 'whole series of things' might be. ${ }^{93}$ There may be sexual intercourse but one partner may be infertile, tempo rarily or permanently; they may use 
contraception; they could be lucky; there could be miscarriage, abortion or stillbirth; and finally, the birth may be falsely registered as legitimate. And we have already seen the range of circumstances of the mothers and fathers that can produce an 'illegitimate' birth, all represented by the same statistics. 94

The number of 'turnings' off the route to registration of an extramarital birth should make plain the minor role played by intercourse in the long chain of events, and therefore the dangers of regarding such births as indicators of sexual activity. These conceptual problems are further developed from a feminist perspective by Gail Reekie, whose analysis of the enduring appeal of such statistics makes uncomfortable reading: 'Illegitimacy statistics were, on the one hand, deadly serious, on the other, titillating and tantalising-a winning combination that may explain why they continue to fascinate social scientists all over the world'. 95

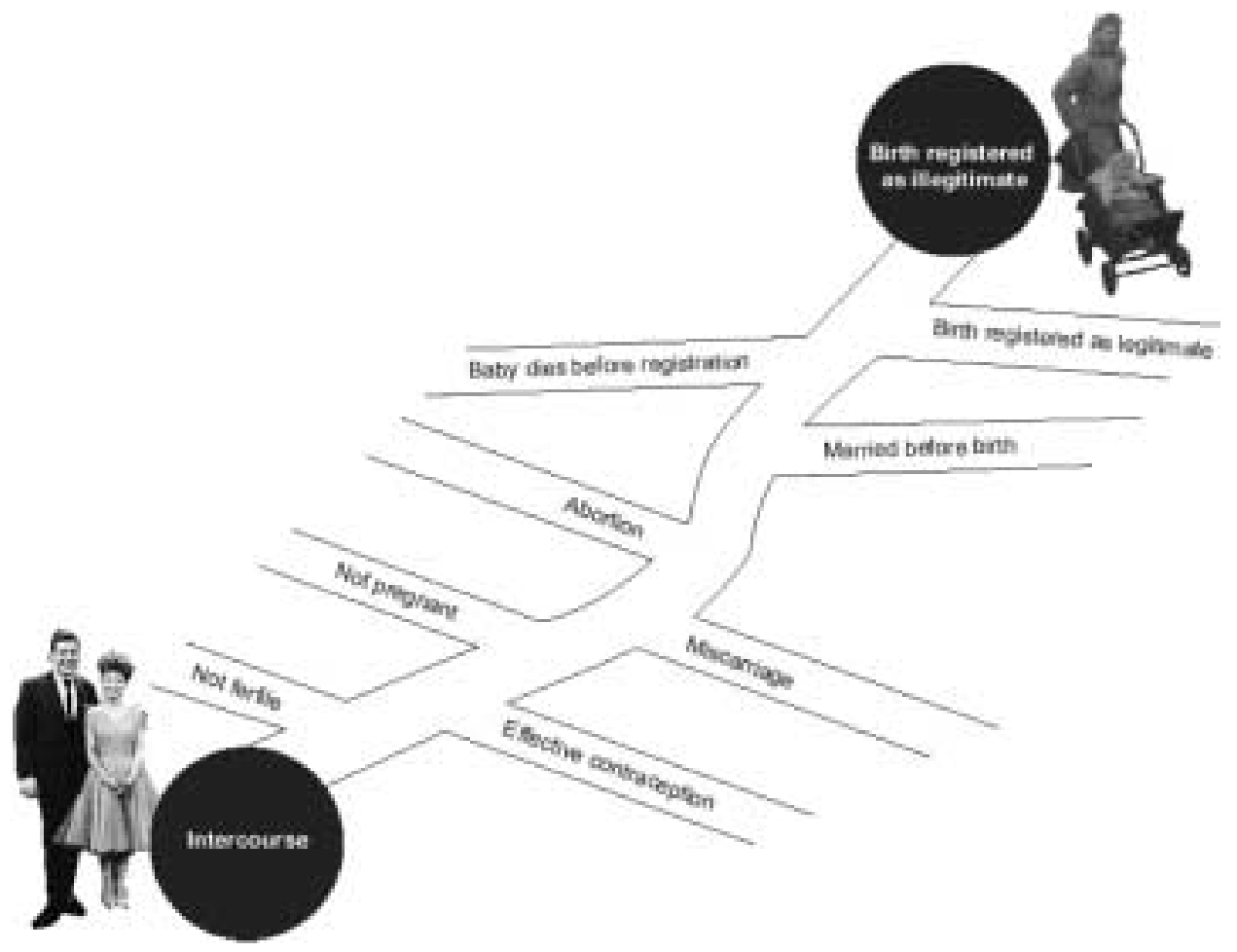

Figure 3. The long route to registering the birth of an 'illegitimate' child. (Illustration by Chantal Oakes.)

\section{Conclusions}


Blackpool's reputation for unusually high rates of birth outside marriage in the mid twentieth century was undeserved. The figures on which this reputation rests took no account of Blackpool's population profile, typical of a tourist centre, with high numbers of single young women and married older women. However, more sophisti cated demographic methods using census population figures are unable to describe Blackpool's births outside marriage with any accuracy because of seasonal migration, rendered invisible in the ten-year snapshot of the census. Blackpool's demography and seasonal economy are far from unique, suggesting that these methodological limita tions affect studies of many other areas. This case study confirms the dangers of using quantitative methods in isolation from qualitative sources that would allow contextu alisation and interpretation of the demographic data. As ever, statistics need to be interrogated.

This local case study raises broader questions about the dichotomies of single/ married and legitimate/illegitimate. 'Illegitimate' children have been constructed as a problem caused by the illicit sexual behaviour of single, never-married women. This view, found in official statistics and policy, the attitudes of social agencies and in cultural representations, highlights the single female among the more numerous other types of women and men who produce children outside the social norms of marriage and parenthood. The stigma of single motherhood was greatly increased by the puni tive, gendered 1834 Poor Law which formalised the sexual double standard and effec tively erased fathers from the picture. These distortions were embedded in the official statistics established in the same decade, which ever since have given an appearance of objective truth and, in circular fashion, have supported the very attitudes that created them.

The category of illegitimacy has an equally circular relationship to the category of marriage. Marriage is one of the strongest influences shaping single-female identities, and increases its status through contrast with its apparent opposite, singleness 96 (although marriage is highly gendered, with less contrast in status between single and married men). Thus the category of female singleness could be used as a dustbin, a place for dirty things such as 'illegitimacy', even though single women were a minority among the mothers of 'illegitimate' children. From the 1930s to the 1950s the border between the lands of the single and the married 
was rigorously policed, resulting in horror at any attempt to blur the boundaries, such as high numbers of pre-marital conceptions, or the desire (usually discouraged) of single women in mother and baby homes to marry the fathers of their children. 97

However, studies of the individuals and families behind illegitimacy statistics show that married/single is not a binary opposition but a continuum, incorporating widowed, divorced, separated, cohabiting and other women between the two poles. ${ }^{98}$ This became more apparent in the 1960s, when cohabitation and sex outside marriage became slightly more acceptable.

The Poor Law still cast its shadow over the middle third of the twentieth century in England, a time when single, never-married women were rarer than ever before, because of the unusual popularity of marriage. Apart from brief moments of respite in the pro-natalist 1930s and the national emergency of the Second World War, single mothers experienced stigma and discrimination, as did their children, who were in consequence more likely to suffer ill health and earlier death.

This article has shown that when these historically contingent ways of classifying and counting certain births are challenged, even on their own terms they are found to be inadequate and misleading. When they are put in the wider context of marriage as a category and the gendered nature of illegitimacy, they have even less value. Unmarried motherhood-and fatherhood-are complex categories, only amenable to investiga tion through current demographic methods if allied to an understanding of the range of meanings that people put on their own and others' sexual behaviour and family arrangements.

\section{Acknowledgements}

I am grateful to Eilidh Garrett, Tom Nutt, Dave Russell, John Walton, Katherine Holden, June Hannam and the two anonymous referees for comments on earlier drafts of this article. 
[1] See S. Humphries (1988) A Secret World of Sex: forbidden fruit: the British experience 19001950 (London: Sidgwick \& Jackson), p. 170; J. K. Walton (1998) Blackpool

(Edinburgh: Edinburgh University Press), p. 72; G. Cross (Ed.) (1990) Worktowners at Blackpool: Mass-Observation and popular leisure in the 1930s (London:

Routledge). In the 1920s, William Woodruff's mother appears to do some temping work in a Blackpool brothel, according to his autobiogra phy: William Woodruff (2000) The Road to Nab End: a Lancashire childhood (London: Eland), pp. 51-53.

[2] Cross (Ed.) Worktowners at Blackpool, pp. 180-181; Walton, Blackpool, pp. 158-159; Humphries, Secret World of Sex, p. 191.

[3] Walton, Blackpool.

[4] In 1931 Blackpool and Great Yarmouth had the highest unemployment rate, 14.7 per cent, of any resort among eighty-three English and Welsh county boroughs; see S. Davies \& B. Morley (1999) County Borough Elections in England and Wales, 1919-1938: a comparative analysis. Vol. 1: Barnsley to Bournemouth (Aldershot: Ashgate), Appendix 2-6, quoted in J. K. Walton (2000) The British Seaside: holidays and resorts in the twentieth century (Manchester: Manchester University Press), pp. 150-151. In 1938, Blackpool had the greatest variation between unem ployment level in season (11.6 per cent) and out of season (24.9 per cent); see E. Brunner (1945) Holiday Making and the Holiday Trades (London: Oxford University Press), pp. 40-42, quoted in Walton, British Seaside, pp. 150-151. Even in the more affluent 1950s and 1960s, Blackpool's winter unemployment peaks made its yearly average higher than most North West industrial towns, see N. Essafi (1990) Some Aspects of Poverty in Blackpool, 1945-60 (MA, University of Lancaster), quoted in Walton, British Seaside, p. 157.

[5] See, for example, L. Chase (1999) The Creation of Place Image in Interwar Clacton and Frinton (Colchester: University of Essex); J. Demetriadi (1994) English and Welsh Seaside Resorts 1950-1974, with Special Reference to Blackpool and Margate (PhD thesis, University of Lancaster); S. Fisher (Ed.) (1997) Recreation and the Sea (Exeter: University of Exeter Press); J. Pimlott (1947) The Englishman's Holiday: a social history (London: Faber \& Faber); G. Shaw \& A. Williams (Eds) (1997) The Rise and Fall of British Coastal Resorts: cultural and economic perspectives (London: Pinter); J. Towner (1996) An Historical Geography of Recreation and Tourism in the Western World 1540-1940 (Chichester: Wiley); J. Travis (1993) The Rise of the Devon Seaside Resorts, 1750-1900 (Exeter: University of Exeter Press); J. K. Walton (1983) The English Seaside Resort, 1750-1914 (Leicester: Leicester University Press); J. Walvin (1978) Beside the Seaside: a social history of the popular seaside holiday (London: Allen Lane).

[6] Walton, British Seaside.

[7] J. K. Walton (1997) The Seaside Resorts of England and Wales 1900-1950, in Shaw \& Williams (Eds) Rise and Fall, p. 21. [8] Walton, Blackpool, p. 149.

[9] Walton, British Seaside, p. 32; Walton, Blackpool, pp. 108, 136.

[10] A 1947 Hulton Press survey found that, among young (mostly unmarried) adults in routine clerical and skilled manual jobs, 81 per cent of women took holidays away from home, compared with 58 per cent of men. Walton, British Seaside, p. 61.

[11] M. Thea Sinclair (1997) Issues and Theories of Gender and Work in Tourism, in M. 
Thea Sinclair (Ed.) Gender, Work and Tourism (London: Routledge), p. 5.

[12] J. K. Walton (1978) The Blackpool Landlady: a social history (Manchester: Manchester University Press), p. 85.

[13] Cross (Ed.), Worktowners at Blackpool, pp. 180-181. Although the bulk of the report was not published until 1990, it appears that some findings were publicised in the press at the time, p. 190.

[14] Thomas R. Malthus (1803) An Essay on the Principle of Population, 2nd edn (London: J. Johnson); L. Cody (2000) The Politics of Illegitimacy in an Age of Reform: women, repro duction, and political economy in England's New Poor Law of 1834, Journal of Women's History, 11, pp. 131-156.

[15] On the importance placed upon paternal financial responsibility for the maintenance of ille gitimate children under the pre-1834 Poor Law, see T. Nutt (2006) Illegitimacy and the Poor Law in Late-Eighteenth and Early-Nineteenth-Century England (PhD thesis, University of Cambridge).

[16] S. Foster Hartley (1975) Illegitimacy (London: University of California Press); M. Hopkirk (1949) Nobody Wanted Sam: the story of the unwelcomed child, 1530-1948 (London: Murray); D. Gill (1977) Illegitimacy, Sexuality and the Status of Women (Oxford: Blackwell); V. Wimperis (1960) The Unmarried Mother and her Child (London: George, Allen \& Unwin); K. Kiernan, H. Land \& J. Lewis (1998) Lone Motherhood in Twentieth-Century Britain: from footnote to front page (Oxford: Oxford University Press).

[17] H. J. Graff (2001) The Shock of the 'New' (Histories), Journal of Social Science History, 25 , pp. 492, 494. For historical demography touching on births outside marriage, see A. J. Coale \& S. Cotts Watkins (Eds) (1985) The Decline of Fertility in Europe: the revised proceedings of a conference on the Princeton European Fertility Project (Princeton: Princeton University Press); P. Laslett, K. Oosterveen \& R. M. Smith (Eds) (1980) Bastardy and its Comparative History: studies in the history of illegitimacy and marital nonconformism in Britain, France, Germany, Sweden, North America \& Japan (London: Edward Arnold); R. Woods (2000) The Demography of Victorian England and Wales (Cambridge: Cambridge University Press); E. Shorter, J. Knodel \& E. Van de Walle (1971) The Decline of Non-Marital Fertility in Europe, 1880-1940, Population Studies, 25; N. F. R. Crafts (1982) Illegitimacy in England and Wales in 1911, Journal of Political Economy, 36; S. Szreter (1996) Fertility, Class and Gender in Britain, 1860-1940 (Cambridge: Cambridge University Press).

[18] A. Blaikie, E. Garrett \& R. Davies (2005) Migration, Living Strategies and Illegitimate Childbearing: a comparison of two Scottish settings, 1871-1881, in A. Levene, T. Nutt \& S. Williams (Eds) Illegitimacy in Britain, 1700-1920 (London: Palgrave).

[19] J. Teichman (1982) Illegitimacy: a philosophical examination (Oxford: Blackwell); G. Reekie (1998) Measuring Immorality: social inquiry and the problem of illegitimacy (Cambridge: Cambridge University Press); see also M. Spensky (1992) Producers of Legitimacy: homes for unmarried mothers in the 1950s, in C. Smart (Ed.) Regulating Womanhood: historical essays on marriage, motherhood and sexuality (London: Routledge).

[20] A. Levene, T. Nutt \& S. Williams (2005) Introduction, in Levene et al. (Eds) Illegitimacy, p. 1. [21] J. Fink (1997) Condemned or Condoned? Investigating the problem of unmarried motherhood in England 1945-1960 (PhD thesis, University of Essex), p. 193; J. Fink \& K. Holden (1999) Pictures from the Margins of Marriage: 
representations of spinsters and single mothers in the mid-Victorian novel, interwar Hollywood melodrama and British film of the 1950s and 1960s, Gender and History, 11, pp. 233-255.

[22] Wimperis, The Unmarried Mother, p. 72; J. Lewis \& J. Welshman (1997) The Issue of Never Married Motherhood in Britain, 1920-70, Social History of Medicine, 10, pp. 401-418.

[23] Spensky, 'Producers of Legitimacy', p. 103.

[24] Fink, Condemned or Condoned?, p. 231; Lewis \& Welshman, 'Never-Married Motherhood', p. 401.

[25] K. Kiernan \& V. Estaugh (1993) Cohabitation: extra-marital childbearing and social policy (London: Family Policy Studies Centre), p. 6. [26] Shorter et al., 'Decline', p. 376.

[27] Cross (Ed.) Worktowners at Blackpool, p. 184, L. Stanley (1995) Sex Surveyed 1949-1994: from Mass-Observation's 'Little Kinsey' to the National Survey and the Hite Reports (London: Taylor \& Francis), p. 188.

[28] Fink \& Holden, 'Pictures from the Margins', pp. 238, 240.

[29] Lancaster Diocesan Rescue and Protection Society [hereafter LDRPS] (1959) Annual

Report and Accounts, Talbot Library, Preston. This qualifies Fink's view that voluntary organisations focused on the mothers or the mothers and children together.

[30] Fink, Condemned or Condoned?, p. 266.

[31] Registrar General's Statistical Review of England and Wales [hereafter RG] for 1938-39 (1947) (London: HMSO), p. 179; RG for 1951, p. 10.

[32] LDRPS (1936) Annual Report.

[33] Correspondence between Blackpool Town Clerk and Home Office (National Archives), HO45/17167.

[34] Correspondence between HMI and Board of Education, 1938 (National Archives), ED101/138. [35] LDRPS (1937) Annual Report, p. 6.

[36] Fink \& Holden, 'Pictures from the Margins', pp. 248-249.

[37] J. Goodman (2005) Pedagogy and Sex: Mary Dendy (1855-1933), feeble-minded girls and the

Sandlebridge Schools, 1902-33, History of Education, 34, p. 171. [38] Humphries, Secret World, p. 64.

[39] Fink, Condemned or Condoned?, p. 236; see also J. E. Higson (1955) The Story of a Beginning: an account of pioneer work for moral welfare (London: SPCK), pp. 134135.

[40] J. Bowlby (1953/1977) Childcare and the Growth of Love (Harmondsworth: Penguin); L. Young (1954) Out of Wedlock: a study of the problems of the unmarried mother and her child (New York: McGraw-Hill).

[41] M. Gorsky (2007) Local Leadership in Public Health: the role of the medical officer of health in Britain, 1872-1974, Journal of Epidemiology and Community Health, 61, p. 469.

[42] J. Welshman (1996) In Search of the 'Problem Family': public health and social work in England and Wales 1940-70, Social History of Medicine, 9, p. 457; M. Mitchell (1985) The Effects of Unemployment on the Social Condition of Women and Children in the 1930s, History Workshop Journal, 19, pp. 105-127.

[43] Since 1916 local authorities had been advised to supervise unmarried mothers because of their children's higher morbidity and mortality, Lewis \& Welshman, 'Never- 
Married Motherhood', p. 404. The 1961 Lancashire County Council MOH annual report, for example, prefaces the ratio, among other figures, with the words, 'In accordance with the requirements of the Ministry of Health certain statistics for

1961 relating to mothers and infants are set out below ...' (p. 20)

[44] Kiernan et al., Lone Motherhood, p. 98; Lewis \& Welshman, 'Never-Married

Motherhood', pp. 417-418.

[45] Blackpool MOH, 1930.

[46] Blackpool MOH, 1934, pp. 13, 78.

[47] Blackpool MOH, 1944, p. 9; see also Blackpool MOH, 1941, p. 7. [48] Blackpool MOH, 1947, p. 44.

[49] Fink, Condemned or Condoned?, p. 146. [50] Blackpool MOH, 1968, p. 38.

[51] Gorsky, 'Local Leadership', p. 471.

[52] Lewis \& Welshman, 'Never-Married Motherhood', p. 410; Blackpool MOH, 1962. [53]

Blackpool MOH, 1970, p. 32; Blackpool MOH, 1972, p. 9.

[54] Reekie, Measuring Immorality, p. 2.

[55] Fink, Condemned or Condoned?, p. 336.

[56] Evening Gazette, 'Wartime Problem of Youth', 15 March 1941.

[57] Evening Gazette, news report of Lancashire County Council MOH's annual report (22 October 1965).

[58] P. Smith, 'Adoption Act-a plea for unwanted babies', Gazette \& Herald, 5 September 1942. [59] Evening Gazette, 'Wartime Problem of Youth.'

[60] LDRPS Annual Report, 1957, 1960.

[61] LDRPS Annual Report, 1953, p. 5; Evening Gazette, 'Cheap Imitations of Film Stars', 12 April 1956, p. 3.

[62] Evening Gazette, 'Girls Seek Glamour at Blackpool', 11 March 1939.

[63] Evening Gazette, 'Birth Figures No Reflection on Blackpool-says doctor', 19 March 1959. [64] Blackpool, MOH 1960, p. 12.

[65] Blackpool, MOH 1967, p. 39; Blackpool, MOH 1972. [66] LDRPS Annual Report, 1937, p. 6.

[67] Blackpool MOH, 1947; Walton, Blackpool, p. 137.

[68] P. Tinkler (1995) Sexuality and Citizenship: the state and girls' leisure provision in England, 1939-45, Women's History Review, 4, p. 201.

[69] Cross (Ed.), Worktowners at Blackpool, pp. 185-191. The social research organisation Mass Observation was formed in 1937 , led by Tom Harrisson, to make an anthropological study of the English working class in the same way that he had researched the tribes of the New Hebrides. Volunteer observers, mostly middle-class intellectuals and Oxford undergradu ates, travelled to Bolton in the spring of 1937, and 80 observers followed many of the inhabitants to Blackpool that August. For a detailed critique of the organisation and its methods in Blackpool, see P. Gurney (1997) 'Intersex' and 'Dirty Girls': MassObservation and working-class sexuality in England in the 1930s, Journal of the History of Sexuality, 8, pp. 256-290.

[70] Gurney, 'Intersex', p. 272.

[71] Cross (Ed.), Worktowners at Blackpool, p. 183. [72] Ibid., p. 190.

[73] Reekie, Measuring Immorality, p. 6.

[74] See also Fink, Condemned or Condoned? p. 6, who wisely steered clear of demographic methods for similar reasons.

[75] Cross (Ed.), Worktowners at Blackpool, p. 184, Stanley, Sex Surveyed, p. 188; Humphries, 
Secret World, p. 191; Walton, Blackpool, pp. 158-159.

[76] Hopkirk, Nobody Wanted Sam, p. 170; Gill, Illegitimacy, throughout.

[77] Another reason may be that the husbands of Blackpool landladies were often absent

for long periods, working inland (Walton, Blackpool Landlady, p. 88).

[78] Blaikie et al., 'Migration', p. 144; C. Pooley \& J.Turnbull (1996) Migration and Mobility in

Britain since the Eighteenth Century (London: UCL Press), p. 252; A. Hinde

(1998) Demographic Methods (London: Arnold), p. 276.

[79] Blaikie et al., 'Migration'; C. Jones (2006) Those Whom God Hath Not Joined: a

study of single women and men in nineteenth-century England, paper presented

at the University of the West of England conference entitled 'Single Women in History 1000-2000'.

[80] Oral histories were intended to be the core of this research, until the project took a demo graphic turn.

[81] RG for 1964, Part III, (London: HMSO) p. 64; D. Pearce \& S. Farid (1977) Illegitimate

Births: changing patterns, Population Trends, 9, p. 21. See also S. Ferguson \& H.

Fitzgerald (1954) Studies in the Social Services (London: HMSO and Routledge), p.

98, quoted in J. Fink (2000) Natural Mothers, Putative Fathers, and Innocent

Children: the definition and regulation of parental relationships outside

marriage in England, 1945-1959, Journal of Family History, 25, pp. 178-195, and

Sunday Times, 'Illegitimacy inside Marriage', 8 July 1973, p. 13.

[82] S. Foster Hartley (1969) Illegitimacy among 'Married' Women in England and Wales, Journal of Marriage and the Family, 31, pp. 793-798.

[83] A. J. Coale \& R. Treadway (1985) A Summary of the Changing Distribution of Overall Fertility, Marital Fertility and the Proportion Married in the Provinces of Europe, in Coale \& Watkins (Eds) Decline of Fertility, p. 70.

[84] Kiernan \& Estaugh, Cohabitation, p. 5. [85] Ibid.

[86] J. Klein (2005) Irregular Marriages: unorthodox working-class domestic life in Liverpool, Birmingham, and Manchester, 1900-1939, Journal of Family History, 30, pp. 210-211.

[87] Cross (Ed.), Worktowners at Blackpool, p. 184, Stanley, Sex Surveyed, p. 188. [88]

Humphries, Secret World, p. 191.

[89] Szreter, Fertility, p. 460.

[90] H. Cook (2004) The Long Sexual Revolution: English women, sex, and contraception 18001975 (Oxford: Oxford University Press), p. 101.

[91] Blaikie et al. came to similar conclusions: 'the Scottish civil registers, linked to the census enumerators' books ... are ... beginning to shed doubt on whether the tools for measuring levels of illegitimacy are as informative as historians of bastardy would wish' ('Migration', p. 167).

[92] Laslett et al. (Eds), Bastardy, p. 52.

[93] The diagram summarises points made in Laslett et al. (Eds), Bastardy, p. 52 and P.

Cutright (1971) Illegitimacy: myths, causes and cures, Family Planning

Perspectives, 3, quoted in Shorter et al., 'Decline', p. 381.

[94] Fink, Condemned or Condoned? p. 226; see also Wimperis, The Unmarried Mother, p.

343. [95] Reekie, Measuring Immorality, pp. 187, 47.

[96] K. Holden (2005) Imaginary Widows: spinsters, marriage, and the 'Lost Generation' in

Britain after the Great War, Journal of Family History, 30, p. 389.

[97] Fink, Condemned or Condoned? p. 278. From 1938 to 1972, marriage was unusually popular among British women. After low marriage rates in the 1920s and 1930s, 
there was a peak in 1939-40, when rates reached 65.9 per 1000 . They rose again as soon as war ended, reaching 63.5 per 1000 in 1972. This era is peculiar for its low numbers of women who remained single. [98] Fink \& Holden, 'Pictures', p. 234. 